\title{
Manajemen Marketing Sekolah Berbasis Information and Communication Technology
}

\author{
Nur Sobihatul Fajri' ${ }^{1}$, Novan Ardy Wiyani2 \\ 1,2Institut Agama Islam Negeri Purwokerto \\ Email: ${ }^{1}$ nursfajri7@gmail.com, 2fenomenajiwa@gmail.com
}

\begin{abstract}
The purpose of this research is to describe the process of marketing management of an ICT-based school at SMK Citra Bangsa Mandiri Purwokerto. This research uses a qualitative approach with descriptive methods. Data were collected using interview, observation, and documentation techniques. The data collected was then analyzed using Miles and Huberman's model data analysis techniques, namely data reduction, data presentation, and verification. The results of this study indicate that marketing at SMK Citra Bangsa Mandiri Purwokerto is carried out by utilizing ICT especially for school marketing. ICT-based school marketing is carried out through ICT-based school marketing management planning activities, organizing ICT-based school marketing, mobilizing/implementing ICT-based school marketing, supervision of ICTbased school marketing.
\end{abstract}

Keyword. Management; Marketing; School; ICT

Abstrak. Tujuan dalam penelitian ini adalah untuk mendeskripsikan proses manajemen marketing sekolah berbasis ICT di SMK Citra Bangsa Mandiri Purwokerto. Penelitian ini menggunakan pendekatan kualitatif dengan metode deskriptif. Data dikumpulkan dengan menggunakan teknik wawancara, observasi, dan dokumentasi. Data yang telah terkumpulk kemudian dianalisis menggunakan teknik analisis data model Miles dan Huberman, yaitu reduksi data, penyajian data, dan verifikasi. Hasil penelitian ini menunjukan bahwa marketing di SMK Citra Bangsa Mandiri Purwokerto dilakukan dengan memanfaatkan ICT khususnya untuk pemasaran sekolah. Marketing sekolah berbasis ICT dilakukan melalui kegiatan perencanaan manajemen marketing sekolah berbasis ICT, pengorganisasian marketing sekolah berbasis ICT, penggerakan/pelaksanaan marketing sekolah berbasis ICT, dan pengawasan marketing sekolah berbasis ICT.

Kata Kunci. Manajemen; Marketing; Sekolah; ICT

Copyright (C JMPI: Jurnal Manajemen Pendidikan Islam. All Right Reserved.

This is an open access article under the CC BY-NC-ND license

(http://creativecommons.org/licenses/by-nc-nd/4.0/).

\section{A. PENDAHULUAN}

Pada abad 21 setiap organisasi bisnis membutuhkan sebuah keterampilan khusus yang sangat penting yakni kemampuan untuk membangun dan mengelola citra organisasinya. Citra organisasi dalam konteks strategi lembaga sebagai coorporate image management terkait dengan bagaimana publik atau masyarakat memandang organisasi tersebut (Suprapto, 2017). Citra yang positif akan sangat berpengaruh terhadap eksistensi suatu organisasi di tengah masyarakatnya. Cutra yang positif dapat dibangun dan dikembangkan dengan memanfaatkan perkembangan ilmu pengetahuan dan teknologi, di mana kini perkembangannya digerakkan oleh keberadaan jaringan internet (Hasanah,

Vol. 4 No. 2, Desember 2019

J-MPI homepage: http://ejournal.uin-malang.ac.id/index.php/jmpi/index 
2017). Hal itu kemudian memunculkan adanya perangkat yang disebut dengan teknologi informasi dan komunikasi atau information communication and technology (ICT).

Pada sisi yang bersamaan di era revolusi industri 4.0 teknologi informasi dan komunikasi atau Information Communication and Technology (ICT) menjadi perangkat yang dapat merubah suatu keadaan atau kondisi dalam hitungan hari bahkan detik. Pada organisasi bisnis peralatan ICT bekerja tanpa henti dan tanpa batas dengan tujuan untuk memenuhi kebutuhan yang berkembang dalam masyarakat yang semakin dinamis dan kompleks.

Pada sisi yang lain internet pun bukan lagi menjadi sebuah media untuk menjalankan roda bisnis tetapi juga menjadi kebutuhan dan life style mayarakat. Jual beli online sudah menjadi budaya baru yang menciptakan efektivitas dan efisiensi yang lebih tinggi. Setiap negara dituntut untuk mampu mengambil manfaat dari berbagai perkembangan ICT. ICT yang telah memasuki lingkungan bisnis telah menyokong keberhasilan organisasi-organisasi bisnis secara lebih efektif dan efisien (Rusli, 2012).

Perkembangan revolusi industri 4.0 juga berpengaruh pada bidang pendidikan sebagai industri penghasil jasa. Perkembangan ini menuntut suatu lembaga pendidikan untuk berpikir secara kreatif dan inovatif dalam menangkap tantangan serta peluang yang ada. Perkembangan ini juga terjadi pada bidang pemasaran atau marketing dalam lingkup pendidikan. Berbagai strategi dan teknik pemasaran terus dikembangkan secara kreatif dan inovatif sehingga teknik-teknik distribusi dan pemasaran lebih aktif dan agresif. Misalnya, pemasaran via elektronik (electronic marketing) maupun melalui jaringan internet lainnya telah mulai digunakan di bidang pendidikan.

Kemudian pada sisi yang lain inovasi pendidikan merupakan kebutuhan primer yang tidak dapat dihindari. Hal itu menjadikan penggunaan ICT diharapkan mampu memunculkan inovasi pendidikan serta mampu meningkatkan kualitas pendidikan yang berdampak pada arah pencapaian tujuan pendidikan yang lebih baik. Pada dasarnya inovasi dalam bidang pendidikan terletak pada kekuatan berpikir dalam menghasilkan ide sebagai teknologi rancang bangun yang harus dimiliki para teknolog di bidang pendidikan (Deni Darmawan, 2012). Kini sudah selayaknya lembaga-lembaga pendidikan yang ada segera memperkenalkan dan memulai penggunaan ICT di bidang pembelajaran, bidang manajemen, maupun bidang marketing atau pemasaran.

Aktivitas marketing atau pemasaran jasa pendidikan yang dahulu dianggap "tabu" karena berbau bisnis dan cenderung berorientasi pada laba (profit oriented), kini sudah dilakukan secara terbuka dan terang-terangan (David Wijaya, 2016). Pada suatu sekolah, marketing/pemasaran dalam konteks pendidikan merupakan sebuah proses sosial dan manajerial untuk mendapatkan apa yang dibutuhkan dan diinginkan melalui penciptaan penawaran, pertukaran produk yang bernilai dengan pihak lain dalam bidang pendidikan. Pemasaran atau marketing pun menjadi proses yang harus dilakukan oleh sekolah untuk kepentingan penyelenggaraan layanan pendidikan.

Pemasaran ataupun marketing sekolah pada masa sekarang ini menjadi sesuatu yang harus diperhatikan seiring dengan semakin banyaknya sekolah-sekolah baru yang bermunculan yang ini pastinya memunculkan adanya persaingan antar sekolah baru maupun sekolah yang sudah lama berdiri (Sholihah, 2018).

Pada era revolusi industri 4.0 saat ini bentuk marketing sekolah dapat diintegrasikan dengan pemanfaatan ICT di dalamnya. Perkembangan ICT telah menawarkan sebuah alternatif dalam hal pemanfaatanya yang diyakini dapat

Vol. 4 No. 2, Desember 2019

J-MPI homepage: http://ejournal.uin-malang.ac.id/index.php/jmpi/index 
mendorong perubahan percepatan yang akan terjadi di masyarakat, termasuk dalam bidang pendidikan. Selain itu pemasaran dalam hal ini menjadi salah satu upaya lembaga pendidikan dalam menghadapi tantangan dan menangkap peluang dari adanya revolusi industri 4.0 sehingga tidak bertahan dalam keterbelakangan.

Dengan demikian marketing/pemasaran sekolah bisa dilakukan dengan mudah tanpa ada batasan ruang dan waktu untuk melakukannya, dengan pemanfaatan ICT ini juga bisa mengenalkan kualitas sekolah dengan cara efektif dan efisien. Sekolah sebagai salah satu komponen dalam pendidikan yang harus ditingkatkan terus kemampuan dan keterampilannya dalam mengelola sebuah lembaga pendidikan untuk mengenalkan produk pendidikan kepada masyarakat luas yang sesuai dengan perkembangan yang ada dalam masyarakat. Terkait dengan istilah informasi ini, dewasa ini semakin sering terdengar ungkapan yang mengatakan bahwa dunia modern sudah memasuki "era informasi". Artinya semakin disadari oleh banyak pihak bahwa informasi merupakan sumber daya yang makin penting peranannya dalam kehidupan manusia, meskipun teknologi yang digunakannya mungkin tidak dikuasainya (Pramitha, 2017).

Berdasarkan hasil observasi penulis di lapangan penulis menemukan sekolah yang mampu memanfaatkan ICT untuk kepentingan marketing. Sekolah tersebut adalah SMK Citra Bangsa Mandiri Purwokerto. SMK tersebut merupakan salah satu sekolah swasta dengan akreditasi A dari tahun 2013 yang tergolong unggul, berkembang dan banyak diminati oleh masyarakat luas baik dari dalam maupun luar daerah. Sekolah tersebut berkembang pesat di antara lembaga-lembaga pendidikan lainnya dan menjadi pilihan masyarakat serta berhasil mendapatkan kepercayaan.

Terdapat banyak kegiatan positif yang diselenggarakan oleh SMK Citra Bangsa Mandiri Purwokerto untuk meningkatkan keahlian para siswa sesuai dengan bakat dan minat yang siswa miliki. Kegiatan tersebut meliputi kegiatan wajib dan ada kegiatan yang disesuaikan dengan bakat dan minat masing-masing siwa. Kegiatan yang wajib diikuti siswa di SMK Citra Bangsa Mandiri Purwokerto meliputi: Pramuka dan Beladiri. Sedangkan kegiatan yang disesuaikan dengan bakat minat siswa yang ada di SMK Citra Bangsa Mandiri Purwokerto, di antaranya meliputi: Paduan Suara, Seni Musik, Tari, Teater, Karya Ilmiah Remaja (KIR), Rohis, OSIS, dan bidang olah raga yang beragam macamnya.

Dalam memperkenalkan jasa pendidikannya, SMK Citra Bangsa Mandiri Tanjung, Purwokerto Selatan, Kabupaten Banyumas melakukan berbagai kegiatan yang dijadikan sebagai program pemasaran jasa pendidikan SMK Citra Bangsa Mandiri Purwokerto. Diketahui pemasaran jasa pendidikan yang dilakukan SMK Citra Bangsa Mandiri Purwokerto memanfaatkan perkembangan teknologi yang terjadi belakangan ini.

Pelaksanaan pemasaran melalui internet di SMK Citra Bangsa Mandiri Purwokerto sebagai salah satu upaya untuk menghindari terjadinya sesutu yang tidak diinginkan, di mana teknologi merupakan salah satu kekuatan yang memberikan dampak sangat besar terhadap organisasi sekolah. Dengan demikian adanya marketing sekolah berbasis ICT di SMK Citra Bangsa Mandiri Purwokerto sangatlah dibutuhkan salah satu upaya sekolah dalam menghadapi perubahan masyarakat yang sangat pesat terhadap internet sebagai dampak dari perubahan revolusi industri 4.0. Hal itu menjadikan penulis tertarik untuk mendapatkan deskripsi tentang bagaimana manajemen marketing sekolah berbasis ICT di SMK Citra Bangsa Mandiri Purwokerto dilakukan.

Vol. 4 No. 2, Desember 2019

J-MPI homepage: http://ejournal.uin-malang.ac.id/index.php/jmpi/index 


\section{B. METODE}

Pendekatan penelitian yang digunakan dalam penelitian ini adalah pendekatan penelitian kualitatif dengan menggunakan metode penelitian deskriptif. Data dikumpulkan dengan menggunakan teknik wawancara, teknik observasi, dan teknik dokumentasi. Data yang telah terkumpul kemudian diuji kevalidannya dan keabsahannya menggunakan teknik triangulasi teknik pengumpulan data, di mana data dari hasil wawancara kemudian dicek kebenarannya maupun keakuratannya dengan data hasil observasi dan data hasil dokumentasi. Setelah itu dapat kemudian dianalisis menggunakan teknik analisis data model Miles and Huberman dengan melakukan tiga langkah, yaitu reduksi data, display data, dan verifikasi.

\section{HASIL DAN PEMBAHASAN}

Berdasarkan hasil penelitian dapat diketahui bahwa ada empat kegiatan dalam manajemen marketing sekolah berbasis ICT di SMK Citra Bangsa Mandiri Purwokerto. Pertama, perencanaan marketing sekolah berbasis ICT. Perencanaan pada dasarnya merupakan proses penentuan secara matang dan cerdas mengenai apa saja yang hendak dikerjakan di masa yang akan datang dalam rangka mencapai tujuan-tujuan yang telah ditetapkan (Munir \& Zakiyah, 2017). Dalam kegiatan manajemen itu sendiri, perencanaan merupakan kegiatan yang pertama kali dilakukan sebelum dilakukan kegiatan lainnya.

Langkah pertama yang dilakukan dalam perencanaan marketing sekolah berbasis ICT adalah merumuskan tujuan yang hendak dicapai dari kegiatan marketing sekolah. Dalam konteks manajemen, tujuan menjadi satu titik tolak pergerakkan suatu organisasi, termasuk dalam hal ini adalah suatu sekolah (Saefrudin, 2017).

Disadari oleh pihak sekolah bahwa keberadaan ICT lebih memudahkan akses bagi calon siswa untuk mengetahui bagaimana profil sekolah, kegiatan sekolah, prestasi akademik dan sistem pembelajaran yang diterapkan di SMK Citra Bangsa Mandiri Purwokerto. Tujuan adanya pemasaran berbasis ICT di SMK Citra Bangsa Mandiri Purwokerto meliputi: (1) Memperkenalkan SMK Citra Bangsa Mandiri Purwokerto kepada seluruh wilayah nasional bahkan sampai internasional. (2) Selain itu juga untuk memperkokoh nama SMK Citra Bangsa Mandiri Purwokerto dalam dunia pendidikan vokasi khususnya, dan dalam dunia kesehatan, pariwisata dan bisnis pada umumnya. (3) Merekrut sebanyak-banyaknya siswa untuk dapat bergabung bersama SMK Citra Bangsa Mandiri Purwokerto dan berproses secara berkualitas.

Dengan dukungan ICT yang berbanding lurus dengan penggunaan teknologi dimasyarakat diharapkan tujuan pemasaran dapat tercapai lebih maksimal dan dapat memenuhi tuntutan perkembangan zaman/revolusi industri 4.0. Dengan adanya penggunaan ICT di SMK Citra Bangsa Mandiri Purwokerto sudah mensuport tujuan pemasaran itu sendiri. Hal ini dibuktikan dengan adanya pembuatan media sosial untuk menyebarkan informasi sehingga lebih mudah, lebih cepat, lebih efisien dan lebih menarik untuk disampaikan dan diterima oleh masyarakat.

Langkah kedua yang dilakukan dalam perencanaan marketing sekolah berbasis ICT adalah menentukan sasaran pasar. Kepala sekolah mengungkapkan bahwa persiapan atau penentuan yang harus dilakukan oleh pihak sekolah sebelum menentukan sasaran pasar adalah mengetahui seberapa responsif dari tanggapan yang disampaikan dalam media sosial terhadap konten informasi yang diunggah melalui

Vol. 4 No. 2, Desember 2019

J-MPI homepage: http://ejournal.uin-malang.ac.id/index.php/jmpi/index 
setiap akun sekolah yang dimiliki. Tentunya karena membahas tentang metode yang berbasis ICT maka yang harus disiapkan adalah mempersiapkan akun sosial media seperti youtube, instagram, facebook dan yang lainnya yang diisi dengan konten-konten yang berisi informasi mengenai maupun seputar lingkungan sekolah. Menentukan sasaran pasar merupakan hal yang sangat mendukung dalam rangka menyampaikan informasi sekolah secara cepat dan tepat.

Hal-hal yang dilakukan oleh SMK Citra Bangsa Mandiri Purwokerto dalam menentukan sasaran pasar meliputi: (1) Melihat hasil PPDB tahun yang lalu. Dalam mengevaluasi hasil PPDB yang diperhatikan adalah apakah sasaran pasar PPDB tahun kemarin sudah tepat atau belum, baik dalam hal kualitas maupun kuantitas siswa yang masuk ke SMK Citra Bangsa Mandiri Purwokerto. (2) Mengevaluasi proses PPDB tahun lalu. Dalam hal ini SMK Citra Bangsa Mandiri Purwokerto mengevaluasi proses PPDB Tahun kemarin apakah sudah tepat sasaran atau masih terdapat kekurangan yang harus diperbaiki sehingga pemasaran yang dilakukan SMK Citra Bangsa Mandiri Purwokerto dapat sesuai tujuan yang diharapkan. (3) Menentukan strategi pemasaran berbasis ICT ditahun ajaran baru. Setelah mengevaluasi hasil PPDB tahun sebelumnya maka diterapkan strategi pemasaran untuk tahun ajaran baru, yaitu meliputi: (a) Menghitung jumlah siswa SMP/MTs yang akan mendaftar ke sekolah menengah atas dari setiap daerah. (b) Memfokuskan promosi pada setiap daerah yang belum bantyak terjamah. Dalam hal ini promosi yang dilakukan adalah dengan cara presentasi pada sekolahsekolah menengah pertama. (c) Mengidentifikasi karakteristik siswa atau masyarakat didaerah tersebut. (d) Menentukan media promosi yang tepat untuk sasaran pasar tersebut.

Langkah ketiga yang dilakukan dalam perencanaan marketing sekolah berbasis ICT adalah menentukan media ICT yang akan digunakan oleh SMK Citra Bangsa Mandiri Purwokerto dalam kegiatan marketing sekolah. Untuk saat ini, pihak sekolah menggunakan beberapa media yang berkaitan dengan ICT yang notabene adalah alat pemasaran dalam dunia maya atau digital. Untuk sejauh ini yang digunakan oleh pihak sekolah adalah meggunakan beberapa akun sosial media seperti youtube, instagram, facebook serta website resmi sekolah.

Media yang digunakan tersebut dikelola oleh pihak sekolah di mana menggunakan tim tenaga profesional dalam mengelolanya, untuk kemudian tim yang sudah dibentuk sekolah mengembangkan dan mengatur sedemikian rupa, sehingga nantinya siap dipubikasikan oleh pihak sekolah.

Langkah keempat yang dilakukan dalam perencanaan marketing sekolah berbasis ICT adalah mendesain media ICT untuk kepentingan promosi. Dalam hal ini pihak sekolah memilih salah satu gurunya untuk mengelola dan diberi tanggung jawab dalam menggunakan serta mengelolanya. Guru TIK menjadi pihak yang ditunjuk. Dalam masalah desain memang dari pihak sekolah memasrahkan sepenuhnya kepada guru TIK, namun dalam pembagian tugasnya tentu guru TIK tidaklah sendirian. Guru TIK dibantu oleh beberapa guru yaang juga menjadi admin serta melibatkan siswa dalam perjalanan pembuatan konten yang berkaitan dengan lingkungan sekolah.

Jadi pihak sekolah mempercayakan masalah desain dalam kegiatan pemasaran sekolah kepada salah satu tenaga pendidik yang memang sudah ahli dalam bidangnya. Untuk dapat menarik minat masyarakat dalam ketertarikannya kepada SMK Citra Bangsa Mandiri Purwokerto maka sangatlah diperlukan kreativitas dan juga inovasi

Vol. 4 No. 2, Desember 2019

J-MPI homepage: http://ejournal.uin-malang.ac.id/index.php/jmpi/index 
dalam setiap unggahan konten yang disajikan, adapun kreativitas itu sendiri adalah hasil dari pemikiran atau ide-ide yang telah disiapkan sedemikian rupa yang telah siap dituangkan melalui sebuah karya.

Untuk menyajikan konten-konten dalam setiap unggahan sosial media, maka sangat dibutuhkan ide-ide yang mampu melahirkan pemikiran yang mampu menunjang dan mengangkat citra sekolah. Jika hanya mengandalkan dan menunggu hasil kreativitas guru saja tentu kurang produktif, maka biasanya guru akan melibatkan siswa dalam mendesain dan menyajikan konten-konten untuk kepentingan marketing sekolah.

Tahap perencanaan dilaksanakan melalui rapat dengan seluruh guru dan staf yang kemudian menentukan langkah-langkah yang akan dilaksanakan kedepannya dalam jangka waktu tertentu. Penyelenggaraan rapat biasanya dilaksanakan secara tidak terduga atau terjadwal apabila ada hal penting yang harus dibahas dengan seluruh guru dan staff sekolah.

Pemasaran atau marketing sekolah untuk era saat ini tidaklah cukup menggunakan metode door to door atau terjun ke sekolah-sekolah secara langsung, namun era sekarang haruslah mengikuti perkembangan teknologi yang semakin berkembang pesat. Dalam hal pemanfaatan ICT memang sangat luas manfaatnya, pemanfaatan ICT dalam pendidikan ini juga seiring dengan adanya perkembangan zaman. Perkembangan ini juga merupakan simbol perubahan yang sedang berlangsung di mana teknologi menjadi media baru yang menawarkan model baru dalam komunikasi, belajar, dan bermain. Teknologi media yang baru dapat mengubah dan memperluas wawasan dalam aktivitas komunikasi sehari-hari dalam ikut berperan membantu pekerjaan yang dilakukan.

Berdasarkan deskripsi di atas dapat diketahui bahwa pada kegiatan perencanaan dilakukan empat langkah, yaitu perumusan tujuan yang hendak dicapai dalam marketing sekolah berbasis ICT, menentukan sasaran pasar, menentukan media ICT yang akan digunakan, serta mendesain media ICT yang akan digunakan. Langkah dalam perencanaan marketing sekolah tersebut berbeda dengan langkah dalam perencanaan marketing sekolah pada umumnya. Secara umum kegiatan yang dilakukan dalam perencanaan marketing antara lain persiapan kegiatan marketing, penentuan target marketing, dan sosialisasi marketing (Sopwandin, 2019).

Kegiatan kedua dalam manajemen marketing sekolah berbasis ICT di SMK Citra Bangsa Mandiri Purwokerto adalah pengorganisasian. Berdasarkan hasil penelitian dapat diketahui bahwa pengorganisasian dan penetapan personal dalam suatu kegiatan didasarkan pada struktur organisasi sekolah.

Dalam kegiatan pemasaran sekolah yang ada di SMK Citra Bangsa Mandiri Purwokerto, kepala sekolah dijadikan sebagai penanggung jawab, kemudian penanggung jawab penerimaan peserta didik baru adalah tim PPDB yang melibatkan banyak pesonil dari kesiswaan yang dibentuk oleh pihak sekolah dengan pertimbangan penanggung jawab kesiswaan lebih memahami kondisi yang akan menjadi pelaksanaan dalam kegiatan pemasaran sekolah tersebut. Pembuatan struktur organisasi oleh kepala sekolah dilakukan untuk memperjelas tugas masing-masing pihak yang terlibat dalam kegiatan marketing sekolah.

Dalam hal pengorganisasian perlu dijalin komunikasi agar hubungan antar masingmasing stakeholders mampu bersinergi satu sama lain tanpa adanya kesalahpahaman. SMK Cita Bangsa Mandiri Purwokerto melakukan komunikasi dengan semua komponenya baik itu guru, komite, karyawan dan yang lainnya melalui rapat-rapat yang

Vol. 4 No. 2, Desember 2019

J-MPI homepage: http://ejournal.uin-malang.ac.id/index.php/jmpi/index 
dilaksanakan terkait semua kegiatan yang akan dilakukan oleh SMK Citra Bangsa Mandiri Purwokerto.

Rapat menjadi salah satu bentuk komunikasi yang dibangun oleh sekolah sebagai bentuk koordinasi. Informasi yang disampaikan oleh SMK Citra Bangsa Mandiri Purwokerto kepada seluruh komponennya selain melalui rapat juga melalui media sosial yang sekolah miliki karena ini sangat memudahkan sekolah secara cepat dan tepat informasi itu disampaikan.

Komunikasi tentunya menjadi hal yang penting, hal ini sebagai bentuk koordinasi dan sosialisasi. Sosialisasi ini sebagi media penyampai informasi yang disampaikan kepada seluruh komponen SMK Citra Bangsa Mandiri Puwokerto maupun masyarakat luar, hal ini dilakukan dengan cara: (1) Memperkenalkan seluruh media sosial kepada warga sekolah yang meliputi tenaga pendidik, tenaga kependidikan dan siswa. (2) Menghimbau atau mewajibkan seluruh komponen warga Citra Bangsa Mandiri Purwokerto untuk menggunakan dan aktif dalam menggunakan media tersebut. (3) Memperkenalkan media pemasaran sekolah kepada siswa menengah atas untuk turut berpartisipasi dan aktif mencari informasi melalui media sosial yang dimiliki oleh SMK CBM Purwokerto.

Adapun pihak-pihak yang terlibat dalam pemasaran sekolah meliputi seluruh warga sekolah dan warga di luar sekolah. Berdasarkan hasil penelitian dapat diketahui bahwa kegiatan pemasaran berbasis ICT di SMK Citra Bangsa Mandiri Purwokerto sudah terorganisir dengan baik. Hal itu dilakukan untuk mengoptimalkan kegiatan pelaksanaan pemasaran nantinya, sehingga dapat mencapai tujuan yang diinginkan. Dalam kegiatan pemasaran sekolah, pihak SMK Citra Bangsa Mandiri Purwokerto telah menetapkan tim khusus, tim ini dibentuk khusus untuk kegiatan pemasaran SMK Citra Bangsa Mandiri Purwokerto. Tim tersebut kemudian menjadi tim dalam panitia penerimaan peserta didik baru (PPDB).

Berdasarkan hasil penelitian dapat diketahui bahwa pada dasarnya dalam pengorganisasian marketing sekolah berbasis ICT dilakukan melalui tiga kegiatan, yaitu penentuan stakeholders dalam kegiatan markering, pembuatan tugas pokok dan fungsi setiap stakeholders, serta menjalin komunikasi antar stakeholders untuk kepentingan kegiatan marketing sekolah. Komunikasi yang terjalin secara intensif dapat memudahkan setiap stakeholders untuk mencapai tujuan marketing sekolah berbasis ICT. Komunikasi yang terjalin antar stakeholders juga dapat menjadi media menciptakan kenyamanan dan keramahan dalam bekerja, tentunya dalam pelaksanaan kegiatan marketing sekolah berbasis ICT. Kenyamanan dan keramahan tersebut akan berimplikasi pada terciptanya iklim kerja yang kondusif, produktivitas kerja dan terciptanya layanan pendidikan yang prima (Puspitasari, 2019).

Kegiatan ketiga dalam manajemen marketing sekolah berbasis ICT di SMK Citra Bangsa Mandiri Purwokerto adalah penggerakkan atau pelaksanaan. Berdasarkan hasil penelitian dapat diketahui bahwa penggerakkan atau pelaksanaan marketing sekolah berbasis ICT sudah sesuai dengan perencanaan yang sudah dirumuskan. Kegiatan marketing sekolah berbasis ICT pada tahun pelajaran 2018/2019 secara lebih optimal dilaksanakan pada waktu menjelang tahun ajaran baru atau sebelum penerimaan peserta didik baru dari bulan Februari hingga bulan juni 2019.

Adapun media yang dominan digunakan sebagai penggerak dalam pemasaran berbasis ICT di SMK Citra Bangsa Mandiri Purwokerto adalah komputer dan internet

Vol. 4 No. 2, Desember 2019

J-MPI homepage: http://ejournal.uin-malang.ac.id/index.php/jmpi/index 
yang digunakan sebagai media untuk mengakses media sosial, media cetak elektronik, membuat lembar presentasi promosi ke sekolah tingkat menengah pertama, serta untuk membuat banner/baliho. Adapun media sosial yang digunakan untuk pemasaran berbasis ICT di SMK CBM Purwokerto yaitu: (1) Facebook (SMK CBM Official), (2) Instagram (smk_cbm_official), (3) Youtube (SMK CBM Official), dan (4) WEB (cfa.smkcbm.sch.id).

Selain menggunakan media komputer dan internet, pemasaran berbasis ICT di SMK CBM Purwokerto juga menggunakan radio, media cetak, presentasi ke sekolah tingkat menengah pertama, program pengabdian masyarakat dan pemasangan banner/baliho di beberapa titik di sudut kota maupun tempat yang strategis di daerahdaerah kabupaten Banyumas pada umumnya.

Dalam hal ini, SMK Citra Bangsa Mandiri Purwokerto melakukan kegiatan pelaksanaan marketing sekolah mulai dari kegiatan promosi melalui media cetak ataupun melalui media massa. Semua ditujukan dengan harapan agar menarik minat bagi peserta didik baru dan masyarakat. Berikut adalah contoh halaman beranda instagram yang digunakan untuk kepentingan PPDB:

Gambar 1. Postingan dalam akun Instagram

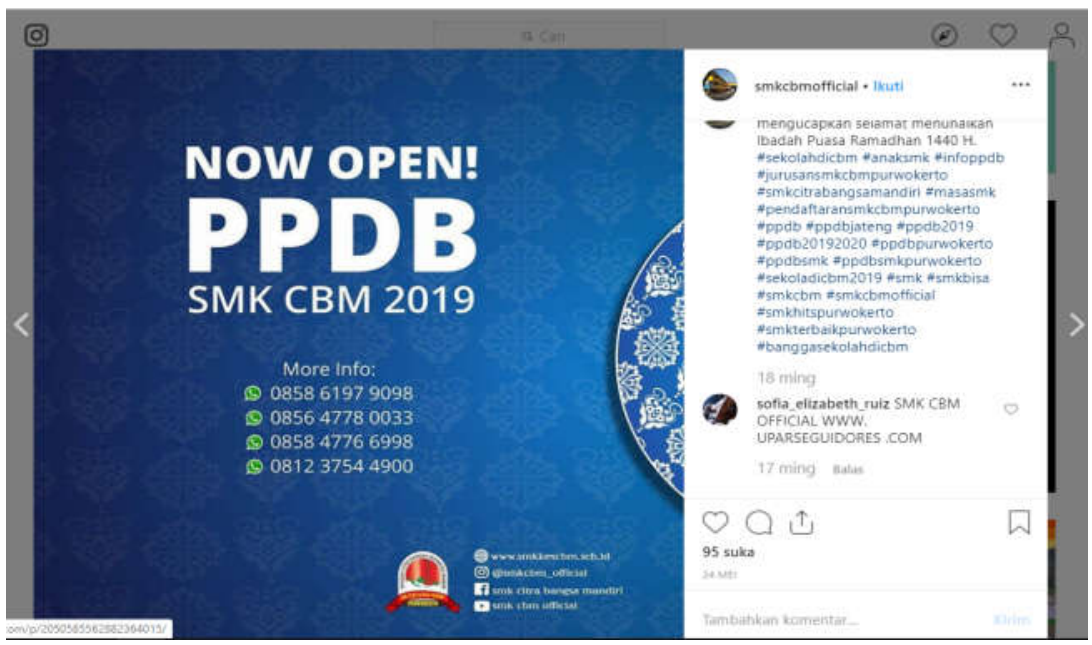

Sumber: halaman beranda Instagram SMK Citra Bangsa Mandiri Purwokerto)

Dalam unggahan di atas pihak sekolah menginformasikan bahwa untuk pendaftaran peserta didik baru bisa diikuti dengan cara mengikuti atau mem-follow setiap akun media sosial yang dimiliki oleh SMK Citra Bangsa Mandiri Purwokerto, karena penginformasian seputar sekolah akan mereka unggah melalui sosial media dari sekolah dan akan mudah diakses oleh siapapun demi mendapatkan informasinya. Untuk instagram penggunaannya memang lebih intens karena pihak sekolah lebih aktif dalam menggunakannya dan karena selain itu juga sosial media instagram lebih mudah digunakan dalam pengunggahan dan isi konten yang disajikan.

Perkembangan teknologi informasi yang semakin pesat di era globasasi saat ini tidak bisa dihindari lagi pengaruhnya terhadap dunia pendidikan. Tuntutan global menuntut dunia pendidikan untuk selalu senantiasa menyesuaikan perkembangan teknologi terhadap usaha dalam meningkatkan mutu pendidikan, terutama dalam 
penyesuaian dalam penggunaan teknologi informasi dan komunikasi bagi dunia pendidikan. Dunia komunikasi tidak seperti dulu lagi. Teknologi informasi secara radikal telah mengubah cara manusia berkomunikasi.

Selain itu teknologi informasi memungkinkan penggunanya untuk dapat diakses sepenuhnya, setiap saat dan dimanapun mereka berada. Komunikasi dan pertukaran informasi antar satu orang dengan orang lain tidak lagi dibatasi oleh waktu, lokasi. Beberapa pemanfaatan ICT, yaitu melalui radio, televisi, komputer dan internet (Hamzah B. Uno dan Nino Lamatenggo, 2011).

Seperti yang diharapkan oleh SMK Citra Bangsa Mandiri Purwokerto dengan memanfaatkan ICT ini juga diharapkan dapat memudahkan baik pihak sekolah dalam menyampaikan informasi tentang SMK Citra Bangsa Mandiri Purwokerto kepada masyarakat luas tanpa terkecuali. Masyarkat akan dimudahkan dalam mencari informasi tentang SMK Citra Bangsa Mandiri Purwokerto dengan mudah walaupun secara jarak sulit untuk dijangkau, namun dengan adanya teknologi informasi jarak bukan lagi menjadi kendala.

Berdasarkan data di atas dapatlah dikatakan bahwa penggerakan atau pelaksanaan marketing sekolah berbasis ICT di SMK Citra Bangsa Mandiri Purwokerto sudah berlangsung secara efektif. Indikasinya adalah pelaksanaan berlangsung sesuai dengan rencana, target-target yang telah ditetapkan juga dapat direalisasikan, serta keberadaan media sosial dan website untuk kepentingan marketing benar-benar bisa diakses oleh calon peserta didik baru maupun masyarakat.

Pada dasarnya efektivitas adalah arti derajat kesesuaian antara tujuan dan sasaran dengan keluaran/hasil dengan memperhitungkan dampak (Mulyono, 2016). Berdasarkan hasil penelitian Rusmaini dapat diketahui bahwa efektivitas dalam pelaksanaan suatu aktivitas akan mengarah pada ketercapaian tujuan secara optimal. Efektivitas juga menjadi suatu dasar pembentukan budaya kerja maupun lingkungan kerja yang kondusif pada suatu lembaga pendidikan. Noer Rohmah mengungkapkan bahwa budaya kerja pada dasarnya merupakan kebiasaan yang harus ditaati dalam rangka melaksanakan suatu pekerjaan untuk mencapai sebuah keberhasilan (Rohmah, 2016). Kemudian ksistensi suatu lembaga pendidikan pun sangat dipengaruhi oleh efektivitas kerja sumber dayanya di bidang manapun, termasuk di bidang marketing (Rusmaini, 2018).

Kegiatan keempat dalam manajemen marketing sekolah berbasis ICT di SMK Citra Bangsa Mandiri Purwokerto adalah pengawasan. Pengawasan dalam suatu lembaga pendidikan lebih ditunjukan kepada tingkat loyalitas setiap pegawai dalam melaksanakan tugas dan kewajiban, apakah sesuai dengan prosedur dan ketentuan yang telah digariskan atau tidak sehingga kejelasan tugas-tugas yang harusnya dilaksanakan sesuai dengan kedudukan dan posisinya itu akan menjadi sorotan dalam melaksanakan tugasnya.

Berdasarkan hasil penelitian dapat diperoleh data bahwa kepala sekolah melakukan kegiatan pengawasan sesuai dengan kalender sekolah yang telah ditetapkan, yaitu selama proses pelaksanaan pembelajaran berlangsung, tidak hanya ketika akhir semester. Ini karena setiap agenda yang telah dibuat haruslah dikawal untuk mengetahui seberapa jauh tingkat pencapaian dari tujuan yang telah ditentukan serta untuk mengetahui kendala-kendala yang dihadapi.

Vol. 4 No. 2, Desember 2019

J-MPI homepage: http://ejournal.uin-malang.ac.id/index.php/jmpi/index 
Sementara itu mengenai pengawasan terkait kegiatan marketing sekolah yang berbasis ICT (Information and Communication Technology) SMK Citra Bangsa Mandiri Purwokerto menekankan pada pemasaran melalui akun sosial media yang mereka miliki dan juga website sekolah yang memiliki informasi inti terkait lingkungan sekolah. Adapun hasil penjelasan dari kepala sekolah mengenai pemasaran sekolah dengan metode berbasis ICT adalah suatu keharusan yang mesti dilakukan pihak sekolah dalam perjalanannya. Mengenai hal ini kepala sekolah memberikan penjelasan bahwa pihak sekolah harus selalu melakukan pembaruan dalam setiap apa yang disajikan dalam media sosial untuk kepentingan promosi, sebab selera masyarakat selalu berubah dan mudah bosan dengan hal yang kurang variatif.

Pihak yang terlibat dalam kegiatan marketing sekolah berbasis ICT secara langsung dituntut untuk mengikuti fenomena yang ada. Deskripsi tersebut menjadi bukti bahwa SMK Citra Bangsa Mandiri Purwokerto sangatlah sadar akan arti penting ICT yang harus mereka gunakan dan konsumsi untuk kepentingan mempertahankan eksistensi dari sekolah.

Dari data yang diperoleh penulis, pengawasan yang dilakukan kepala SMK Citra Bangsa Mandiri Purwokerto dilakukan dengan terlibat secara langsung dalam proses pengawasan. Kepala sekolah meminta laporan pertanggung jawaban kepada panitia penerimaan peserta didik baru baik dalam bentuk lisan maupun tulisan. Laporan tersebut diserahkan ke kepala sekolah setelah guru selesai dalam tugasnya.

Kegiatan evaluasi yang dilakukan SMK Citra Bangsa Mandiri tidak hanya dilakukan di akhir saja melainkan juga dalam prosesnya, perbulan, tengah semester, akhir semester dan akhir tahun. Pada kegiatan evaluasi dibahas tentang programprogran mana yang perlu diperbaiki dan mana yang perlu dihapus, jika ada suatu kendala maka akan dipecahkan bersama dan dicari solusinya, dalam evaluasi juga membahas program tentang persiapan program kegiatan terdekat yang akan dilaksanakan berikutnya agar lebih matang dalam pelaksanaannya.

Berdasarkan deskripsi di atas dapat diketahui bahwa kegiatan pengawasan marketing sekolah berbasis ICT bukan hanya dilakukan untuk menilai keberhasilan dalam pencapaian tujuan tetapi juga untuk mendiagnosa kendala-kendala dalam pelaksanaan marketing sekolah berbasis ICT. Dengan demikian dengan adanya pengawasan maka para guru yang terlibat dalam pelaksaanaan marketing sekolah berbasis ICT kinerjanya akan lebih terkontrol dan terarah untuk mencapai tujuan. Hal ini selaras dengan penelitian Ayu Alfiatur Rohma yang mengungkapkan bahwa pengawasan merupakan suatu proses yang sistematis untuk memastikan suatu proses berjalan sesuai dengan apa yang telah direncanakan (Rohma, 2018).

\section{KESIMPULAN}

Pada era sekarang ini keberadaan teknologi ikut menentukan eksistensi suatu lembaga pendidikan atau sekolah. Ini karena penyelengaraan layanan pendidikan di berbagai bidang tidak lepas dari penggunaan teknologi. Sekarang ini di era revolusi industri 4.0 ICT (Information and Communication Technology) menjadi suatu media yang harus ada dan harus dimanfaatkan oleh sekolah untuk menyelenggarakan layanan pendidikan. ICT dapat digunakan oleh pihak sekolah bukan hanya untuk menyelenggarakan kegiatan pembelajaran yang inovatif tetapi juga untuk melaksanakan

Vol. 4 No. 2, Desember 2019

J-MPI homepage: http://ejournal.uin-malang.ac.id/index.php/jmpi/index 
kegiatan pemasaran atau marketing sekolah. Hal inilah yang kemudian memunculkan istilah marketing sekolah berbasis ICT.

SMK CBM Purwokerto merupakan salah satu sekolah yang mampu memanfaatkan ICT sebagai media untuk melaksanakan kegiatan marketing sekolah. Berdasarkan hasil penelitian dapat diketahui bahwa manajemen marketing sekolah berbasis ICT di SMK CBM Purwokerto dilakukan melalui empat kegiatan.

Pertama, kegiatan perencanaan marketing sekolah berbasis ICT. Langkah-langkah yang dilakukan dalam kegiatan ini antara lain perumusan tujuan yang hendak dicapai dalam marketing sekolah berbasis ICT, menentukan sasaran pasar, menentukan media ICT yang akan digunakan, serta mendesain media ICT yang akan digunakan. Kedua, kegiatan pengorganisasian marketing sekolah berbasis ICT. Langkah-langkah yang dilakukan dalam kegiatan ini yaitu penentuan stakeholders dalam kegiatan markering, pembuatan tugas pokok dan fungsi setiap stakeholders, serta menjalin komunikasi antar stakeholders untuk kepentingan kegiatan marketing sekolah.

Ketiga, penggerakkan atau pelaksanaan marketing sekolah berbasis ICT. Kegiatan ini merupakan perwujudan dari rencana yang telah dirumuskan. Komputer dan internet menjadi media utama yang digunakan untuk melaksanakan kegiatan marketing sekolah berbasis ICT. Ini karena kegiatan marketing sekolah berbasis ICT dilakukan menggunakan media sosial seperti facebook, instagram, dan what's up, serta website sekolah. Manfaat yang dapat diperoleh dari hal ini adalah adanya budaya kerja paperless serta calon peserta didik baru maupun masyarakat bisa mengakses informasi serta melakukan pendaftaran secara on-line. Keempat, pengawasan marketing sekolah berbasis ICT. Kegiatan ini dilakukan untuk mengetahui ketercapaian tujuan yang telah ditentukan serta untuk mendiagnosa kendala yang ditemui selama pelaksanaan marketing sekolah berbasis ICT berlangsung. Hasilnya kemudian dijadikan sebagai bahan untuk melakukan upaya perbaikan.

\section{REFERENSI}

David Wijaya. (2016). Pemasaran Jasa Pendidikan. Bumi Aksara.

Deni Darmawan. (2012). Inovasi Pendidikan. Rosda.

Hamzah B. Uno dan Nino Lamatenggo. (2011). Teknologi Komunikasi \& Informasi Pembelajaran. Bumi Aksara.

Hasanah, S. M. (2017). Strategi Membangun Global Brand Perguruan Tinggi Keagamaan Islam Negeri (Ptkin) Menuju World Class University. J-MPI (Jurnal Manajemen Pendidikan Islam), 2(2), 128. https:// doi.org/10.18860/jmpi.v2i2.5476

Mulyono, M. (2016). Tantangan Global Dan Upaya Menuju Manajemen Perguruan Tinggi Yang Efisien. J-MPI (Jurnal Manajemen Pendidikan Islam), 1(1). https:/ / doi.org/10.18860/jmpi.v1i1.3233

Munir, M., \& Zakiyah, E. (2017). Manajemen Perubahan Lembaga Pendidikan Islam Di Era Globalisasi. J-MPI (Jurnal Manajemen Pendidikan Islam), 2(2), 114. https:// doi.org/10.18860/jmpi.v2i2.5475

Pramitha, D. (2017). Pergeseran Paradigma Sistem Informasi Manajemen. J-MPI (Jurnal Manajemen Pendidikan Islam), 2(1). https:/ / doi.org/10.18860/jmpi.v2i1.4356

Vol. 4 No. 2, Desember 2019

J-MPI homepage: http://ejournal.uin-malang.ac.id/index.php/jmpi/index 
Puspitasari, F. F. (2019). Implementasi Pelayanan Prima Sebagai Upaya Meningkatkan Marketing Sekolah. J-MPI (Jurnal Manajemen Pendidikan Islam), 4(1), 30. https:// doi.org/10.18860/jmpi.v4i1.7339

Rohma, A. A. (2018). Implementasi Program Kerja Pengawas Dalam Peningkatan Kinerja Guru Pendidikan Agama Islam. J-MPI (Jurnal Manajemen Pendidikan Islam), 3(2), 91. https:// doi.org/10.18860/jmpi.v3i2.6457

Rohmah, N. (2016). Strategi Pimpinan Dalam Peningkatanbudaya Kerja Di Perguruan Tinggi. J-MPI (Jurnal Manajemen Pendidikan Islam), 1(2). https:/ / doi.org/10.18860/jmpi.v1i2.3966

Rusli. (2012). ICT dan Pembelajaran. Referensi.

Rusmaini, R. (2018). Pengaruh Kepemimpinan dan Komunikasi Intern Terhadap Efektivitas Kerja Pegawai di FITK UIN Raden Fatah Palembang. J-MPI (Jurnal Manajemen Pendidikan Islam), 3(2), 49. https://doi.org/10.18860/jmpi.v3i2.6453

Saefrudin, S. (2017). Pengembangan Manajemen Berbasis Sekolah. J-MPI (Jurnal Manajemen Pendidikan Islam), 2(1). https://doi.org/10.18860/jmpi.v2i1.4359

Sholihah, T. (2018). Strategi Manajemen Humas Dalam Menciptakan School Branding Pada Sekolah Islam Terpadu. J-MPI (Jurnal Manajemen Pendidikan Islam), 3(2), 72. https:// doi.org/10.18860/jmpi.v3i2.6455

Sopwandin, I. (2019). Manajemen Pemasaran Pondok Pesantren Berbasis Program Pengabdian Masyarakat. J-MPI (Jurnal Manajemen Pendidikan Islam), 4(2), 78. https:// doi.org/10.18860/jmpi.v4i2.8020

Suprapto, A. (2017). Manajemen Pencitraan Di Madrasah Berprestasi (Madrasah Aliyah Negeri Bangil Dan Madrasah Aliyah Negeri Kraton Pasuruan). J-MPI (Jurnal Manajemen Pendidikan Islam), 1(2). https:/ / doi.org/10.18860/jmpi.v1i2.3962 